\title{
Q.DIALektika
}

ISSN: 2338-2635

\section{AN INVESTIGATION OF ENGLISH DEVELOPMENT OF YOUNG LEARNERS AT STAR KIDS PRESCHOOL}

\author{
Febrimarini Sinulingga \\ Program Studi Sastra Inggris, Fakultas Sastra dan Bahasa, Universitas Kristen Indonesia. \\ febrimarini.sinulingga@uki.ac.id
}

\begin{abstract}
Abstrak
Tujuan dari penelitian ini adalah untuk mengetahui perkembangan bahasa Inggris pelajar muda di prasekolah Star Kids. Ini adalah studi kasus. Pengumpulan data dilakukan melalui observasi dan wawancara semi terstruktur. Sumber data diambil dari guru, orang tua, dan kepala sekolah sebagai perwakilan manajemen sekolah di TK Star Kids. Analisis data menunjukkan bahwa guru di prasekolah Star Kids membantu pelajar muda mengembangkan bahasa Inggris mereka, tetapi pengetahuan tentang pelajar muda masih kurang. Orang tua dan kepala sekolah puas dengan guru karena mereka menjaga komunikasi yang baik. Temuan data menunjukkan bahwa para guru membutuhkan lebih banyak seminar, lokakarya, atau kursus dalam mengajar pelajar muda dengan benar.
\end{abstract}

\section{Kata kunci: investigasi, pengembangan, siswa TK}

\begin{abstract}
The purpose of this study is to investigate the English development of young learners at Star Kids preschool. It is a case study. The data were collected through observations and semi-structured interviews. The data sources were taken from the teachers, the parents, and the headmaster as the school management representative in Star Kids preschool. The data analysis indicated that the teachers in Star Kids preschool help young learners develop their English language, but the knowledge about young learners is still insufficient. The parents and the headmaster satisfy with the teachers since they maintain good communication. The data findings suggest that the teachers need more seminars, workshops, or courses in teaching young learners properly.
\end{abstract}

Keywords: investigation, development, young learners 


\section{Introduction}

The development of education, especially English, in Tanah Karo, North Sumatera, is rapidly increasing lately. It is indicated by the rising number of English schools and courses that held events in English language development. It also affected many preschools that start promoting English as their main language in teaching the class. Parents also do not want their children to miss this opportunity. That is why they are willing to spend much money to give the best English education even though their income is not that good.

According to Eurydice (2006), to provide better opportunities for learning a language, many countries have established bilingual schools where some curricular subjects are taught through a foreign language. The schools in Tanah Karo, North Sumatera are also very aware of this. That is why some private schools and preschools are using English in the learning and teaching process.

Unfortunately, the development of the English language is not very supported by adequate teachers. Most of them are poorly trained in English, and even worse, they have to teach young learners. How can they become a good example when they are not good at using the language? Enthusiasm is certainly not enough reason to teach young learners. It should be balanced with a better knowledge to teach them appropriately because young learners usually copy anything that the teachers do.

Star Kids is one of the bilingual preschools in Tanah Karo, North Sumatera, since 2010. Not all teachers there are getting an education from the English department. Most were recruited because English language development is increasing these days, and they need more teachers to teach. Not only in Star Kids but many private schools or preschools also do the same thing. These schools keep recruiting teachers even though they are lack knowledge in teaching English. They will do anything to keep business on top.

The approach to the young learner is certainly different from an adult. According to the University of Cambridge (2010), there are four key differences between teaching young learners and adults. First, young learners are still developing cognitively, linguistically, socially, emotionally, and physically. Second, young learners often have no obvious reason for learning English. Third, 
AN INVESTIGATION OF ENGLISH DEVELOPMENT OF YOUNG LEARNERS AT STAR KIDS PRESCHOOL

young learners may not always have well-developed literacy skills to support their learning in English. Fourth, young learners often learn slowly and forget quickly. These facts should become the focus of the schools and realize that they need a good teacher to teach their students appropriately.

Sometimes the teachers are not using the right approaches due to a lack of knowledge about the facts above, and in the end, it makes the lesson become a frightening specter. It makes the young learners feel forced to understand everything in a short time. The English language that should be simple, easy, and fun for young learners becomes a burden. It is one of the problems faced by the teachers in Tanah Karo, North Sumatera.

This research investigates the English development of young learners in Star Kids preschool Tanah Karo, North Sumatera. In this research, the writer will explain the characteristics of young learners and the importance of using the right methods and approaches in teaching English for young learners related to the project, describing the research design and data, and summarizing the major findings. By exploring the needs of young learners in learning English, it is hoped that this research will help the teachers in Tanah Karo, North Sumatera, better understand how to teach the learners, especially those who work at a preschool and not from the English department.

\section{Literature review}

This chapter will reveal the characteristics of young learners, teaching English to young learners and methods, and approaches in teaching them.

\section{A. Young Characteristics of Young Learners}

Ersoz (2007) divides young learners into three categories; very young learners, young learners, and older/late young learners. First, very young learners are from age 3-6 years old. In education, it is named preschool age. Their language/skills in listening and speaking should use concrete vocabulary items and use familiar objects in this age. It is better not to use grammar teaching or metalanguage because they cannot analyze language but may be exposed to chunks through songs and classroom language. Better not teach reading and writing too because they may recognize letters or short words. Characteristic in this age usually 
AN INVESTIGATION OF ENGLISH DEVELOPMENT OF YOUNG LEARNERS AT STAR KIDS PRESCHOOL

have low concentration span but easily excited. High motivation with active involvement, love talking but problems in sharing. They have a short memory because, mostly at this age, they learn slowly and forget easily. Repetition and revision are necessary. Most of them have limited motor skills such as using pen and scissors but kinesthetic and energetic. They also learn holistically, love stories, fantasy, imagination, art, drawing, and coloring.

Second, young learners are between the ages of 7-9 years old. In education, they will be placed in grades 1-3. In this age, the language/skills they use in listening and usually speaking concrete in vocabulary and familiar with new objects. They are new in reading and writing (word to sentence level). Same with very young learners, it is better not to use grammar teaching or metalanguage but chunks through songs and classroom language. The characteristic in this age is usually a low concentration span, so a wide variety of activities are needed. They have a short memory, and frequent revision is also needed here. They have logicalanalytical such as asking questions. They have problems in sharing in group work. Start developing confidence in expressing themselves. They also start developing world knowledge. Most will have limited motor skills. They gain to get a reasonable amount of input. At this age, they still love stories, fantasy, imagination, drawing, and coloring.

Third, older/late young learners are between the ages of 10-12 years old. In education, they will be placed in grades 4-6. At this age, the language/skills they use in listening, speaking, and reading usually form concrete vocabulary and tell abstract vocabulary. It is a proper age to teach grammar inductively. The characteristic they have has a longer attention span but still children's age. Start taking learning seriously. More cooperation in groups and pairs because they want to learn about the world. They develop social, motor, and intellectual skills. Learning strategies are used and developing in this age.

\section{B. Teaching English to Young Learners}

From the very early stages of life, babies have a natural tendency to communicate with people around them. As early as their third or fourth day in their social life, they start to recognize faces and first language acquisition commences through the constant interaction of the infant with his/her social circle. The baby is 
AN INVESTIGATION OF ENGLISH DEVELOPMENT OF YOUNG LEARNERS AT STAR KIDS PRESCHOOL

accepted as a new member in social interaction before she/he can talk clearly and step by step developing sound system and lexical items of the first language (or even non-linguistic utterances) are reacted to as act communicative attempts. Meaning is pinpointed in action and interaction (Cameron, 2001).

When children start learning a second or foreign language, they will actively try to participate in the conversation when adults or other children talk. The example that the writer gets here was illustrated by Cameron (2003) by citing a Korean learner teacher experience. The class teacher taught "I like, don't li" by using the topic of their favorite food with plenty of practice of examples such as "I like pizza, don't like hamburger" After a few lessons, the students were introduced with the question "Do you like..." but not with food topic this time, instead, with the names of their classmates' example "Do you like Yong-He". The children were surprised by this question, having linked the idea of liking food and eating. The example helps us to understand how young learners see the foreign language from the inside and try to find meaning in how it is used in action, interaction, and with intention rather than from the outside as system and form. As a result, even if the syllabus taught them that structural children's learning should be communicative as being used with meaning and for action. If teaching materials do not enable children to find meaning in a new language, learning will become a burden. Teaching English to young learners need very good teaching skills, creativity, thorough preparation, and patience. The teachers must have all of these attributes in order to make them motivated to learn English.

Age has a crucial role in what the teacher teaches and how they teach the learners. We can see it clearly when Hammer (2007) shows us the differences between young learners, adolescents, and adults. In this research, the writer will only explain to young learners and adults so the reader can easily see the differences. Young learners respond although they do not understand. They learn from everything around them, and they learn indirectly. They understand when they see, hear, touch, and interact rather than from explanations. Abstract concepts are difficult to deal with in this age. They generally display a curiosity about the world and an enthusiasm for learning a language. They like talking about themselves and respond to learning that uses their lives as the main topic. They love discovering things, making or drawing things using their imagination, moving 
AN INVESTIGATION OF ENGLISH DEVELOPMENT OF YOUNG LEARNERS AT STAR KIDS PRESCHOOL

from one place to another as well as solving puzzles. They have a short attention span and are easily bored after 5-10 minutes. Teachers should have a rich repertoire of activities to help young children recive information from various sources and plan a range of activities for a given period. Teachers should work with students individually or in groups according to their needs. Teachers need to be aware of student's interests to motivate them. The classroom should be colorful, bright with enough room for different activities.

Different from young learners, the adult can engage with abstract thought. They have a whole range of (positive or negative) life and learning experiences. They have expectations about the learning process, and they have their patterns of learning. They are more disciplined than the other age groups and know how to struggle despite boredom. Unlike other groups, they know why they are learning and what they want to have at the end. They sustain a level of motivation even for a distant goal which is difficult for the other groups. They can be critical of teaching methods, or they may feel uncomfortable with unfamiliar methods. Older ones worry that their intellectual powers diminish by age. They have a longer concentration span to continue an activity than the other groups. Teachers should consider their (positive and negative) learning experiences.

Apart from whether or not the generalizations are acceptable, knowledge about children's learning is very important to make the learning process effective. In teaching English to young learners in Star Kids, knowing how they learn the language may become a key point for the teachers to stick on the belief to their teaching method or try a new method that is more sensible. As we know, there have been never-stop arguments in publications convincing that o "learner-center" teaching is better than the "teacher-orient" method of teaching. The teachers in Star Kids might realize it or not. They may sometimes tend to $b$ "teacher-orient" because of a lack of knowledge in teaching young learners.

As have been portrayed by Piaget and Vygotsky (cited in Cameron, 2001), learner-centered teaching will be effective if it is tuned to the pupils' learning needs. Thus, if the teachers are consistent with this idea, they would agree that a learnercentered perspective should be the key point in teaching English to young learners. If they can facilitate the learning process, it will enable the learners to bring 
AN INVESTIGATION OF ENGLISH DEVELOPMENT OF YOUNG LEARNERS AT STAR KIDS PRESCHOOL

curiosity and eagerness to make sense of the world. The teachers may help them

tackle even the most demanding tasks with enthusiasm and willingness (Cameron, 2001). However, if the teachers fail to provide the learners with pleasant learning situations, they may drag the very young learners to the feeling hatred towards the language; in this case, English language.

\section{Methods and Approaches in Teaching English to Young Learners}

Some thoughts can be drawn from the characteristics of young learners given by Ertoz (2007). First, the young learners will need teachers with high qualifications. One who understands the principle of teaching, master the pedagogical qualities, and enthusiastic about entering their world. Second, the young learners need programs, facilities, and various media to help them understand and meet their needs, make satisfactory progress and interact with their world. Colorful-painted walls, classrooms with large windows, spacious library, playground, television sets, videos, computers, and some toys are examples of facilities that can assist them to learn. Third, the method and approach of teaching and learning language have to be pertinent to the unique characteristics of young learners. They must be given treatment relevant to their age and cognitive competence.

In another way, teaching a language to young learners need assistance, guidance, atmosphere, and a conducive environment. They will attain assistance and guidance from their sympathetic, appreciative and thoughtful teachers. At the same time, atmosphere and environment can be created by providing facilities and media to make them aware of their current world. These two important elements, along with other determining elements, are keys to encourage young learners to learn the English language and at the same time dig their potentials. Teachers have the most important role in creating an encouraging emotional atmosphere in the classroom.

Fun learning should be the situation made by the teachers. Children especially have fun with movement and physical participation, and the more fun the learners have, the better they will remember the language learned (Shin, 2006). Due to this statement, Total Physical Response (TPR) can teach English for young learners. It is a very popular method by James Asher (as cited in Larsen-Freeman, 
2001). It requires the children to listen and physically respond to a series of instructions from the teachers (Larsen-Freeman, 2000; Richards \& Rodgers, 2001).

Some of the activities in TPR such as:

- craft activities involve students in making something such as painting, making puppets, origami, play doughs, etc. It can be physically satisfying for very young learners (Shin, 2006). From such activities, the teacher can measure the learners' English development whether they understand the direction or not.

- The singing activity also can be a fun medium to learn English. It will be better to use songs that have moved so the learners can easily remember them. If possible, the teacher can use video music with cartoons to make the learners feel the joy of learning English.

- Role-play activity through storytime can be a good idea to teach English to very young learners. Nevertheless, make sure not to use a long and complicated story. The teacher can use a very simple story since learners at this age have high imagination, especially fantasy stories.

However, the teacher should be careful not to keep the tempo of the lesson at a stable pace. In meaning, activities should not always be physical or fast or vice versa. The teacher needs to consider the learner's energy. Variety activities with different paces and tempos are necessary since the young learners have a short attention span (Scott\&Ytreberg, 2001; Shin, 2006).

Ordinary classroom language such a "Good morning", "Sit down, please "Stand up, please", etc could be one of the activities that can develop their English language. Including routine classroom activities such as painting, singing, reading a story, and building up a core language at the beginning of the year that the learners can handle and use themselves. According to Cameron et al. (2001), pre-existing sound knowledge and recycled language can be provided to the students by establishing routines. These routines should be done consistently in their activities, such as singing, playing, or studying. It will make learners feel secure and maintain motivation as these activities take childrens' attention and ensure the learners know 
AN INVESTIGATION OF ENGLISH DEVELOPMENT OF YOUNG LEARNERS AT STAR KIDS PRESCHOOL

what is going on and what will come next (Brewster et al., 2004; Scott \& Ytreberg,

2001; Shin, 2006).

The learners can also build on this core language by receiving even richer comprehensible input through listening or watching their teacher while reading or telling stories loudly (Mixon \& Temu, 2006). Watching videos and television can be useful in the classroom because they are graded according to the learners' level (5-10 minutes) and in suitable genres such as cartoons, animation, etc. These kinds of activities can be a good time to use English since they focus on the media.

However, no matter which activity the teacher use, the learners should be supported by contextualizing the language with visuals, mime, and gestures (Brewster et al., 2004; Gordon, 2007). It should match the meanings in the stories that teachers tell or sing to provide comprehensible input (Shin, 2006). In addition, the teacher should not forget the importance of peripheral learning: enriching the classroom with printed objects such as posters and flashcards. These media may subconsciously help learners acquire print awareness (Brewser et al., 2004; LarsenFreeman, 2000; Richards \& Rodgers, 2001).

\section{Theoretical Framework}

Case study designs were adopted in this research by using semi-structured interviews and observation. It is used to gain more accurate information about English development for young learners. The teachers were interviewed, and the parents and headmaster, to add more information about English development in Star Kids Preschool.

\section{Methodology}

The methodological design for this research was a case study designed to investigate English development towards young learners. John Gerring, in his review (2004), said that a case study is research characterized by process tracing. That is why the data were taken from the teachers by answering the semi-structured interview items and observations during the class.

The writer's purpose in a case study is not to study everything taking place in a particular location but to focus on specific issues, problems, or programs. In every instance, there must be limitations set. The writer will only observe and 
AN INVESTIGATION OF ENGLISH DEVELOPMENT OF YOUNG LEARNERS AT STAR KIDS PRESCHOOL

interview the teachers, some parents, and the headmaster of Star Kids preschool in Kabanjahe, North Sumatera. All of this was is done to explore the method and approach used to teach English for young learners.

Star Kids preschool is divided into three parts; class one for 2-4 years old, class two for 4-5 years old, and class three 5-6 years. The participants of this research are class one as representative of young learners. Mostly the learners use the Indonesian language as their first language even though Karoness is their mother language. One class consists of fifteen learners with two teachers. Most of the teachers have not graduated from the English department, but they can speak simple English. Observation in the classroom carefully provides not making many temptations to draw teacher's attention from the focus of the study. The writer tries not to disturb the learning process so the result can be seen.

\section{Findings and Discussion}

\section{A. Findings}

This chapter presents the investigation of the English development of young learners in Star Kids preschool. The findings section comprises two parts: findings from observations and semi-structured interviews.

\section{a. Observation findings}

Every morning the learner is greeted by the teachers in the class. They use English to speak English such a "good morni" "how are yo"“smi"“"that's good", etc. The teachers keep smiling to make the learners comfortable while learning. The learners seem eager to learn even though sometimes one or two learners cry because the parents leave the class. However, the teachers always have some way to attract the learners' attention. It means that teachers can gain a positive environment for the young learners.

During the observations, one or two times, the teacher forget to use simple English expressions such as instead saying "good" to praise the learners, the teacher using Indonesian language "bagus". The teachers also using some media to teach, such as pictures, songs, puppets, etc. Sometimes, when reading a story, they speak too fast and make the learners confuse. The story also too long for the young learners and it makes them bored and does another thing like running around the 
AN INVESTIGATION OF ENGLISH DEVELOPMENT OF YOUNG LEARNERS AT STAR KIDS PRESCHOOL

class or making noise. However, overall, the teachers are well prepared to accommodate learners in learning simple English expressions.

From the explanation above, it seems that the teachers were well prepared in teaching the class. They always come before the learners so they can greet them. They are creative in teaching English by using media. They always try their best, so the learners enjoy their time at school. The teachers also maintain communication with the parents to know learners' progress in using the English language.

\section{b. Findings from Semi-structured Interviews}

The semi structured-interviews were given to the teachers, parents, and the headmaster to get more accurate data.

The writer uses the Indonesian language during the interview since not all participants are graduated from the English department. The writer presents her qualitative results by identifying three themes and subthemes related to the teachers towards young learners. The first theme is about teacher's knowledge about young learners and the theme's characteristics. Second, the theme is about the media that the teachers used in teaching English, and the subthemes are pictures, videos, puppets, songs, and other media that they use to teach. Third, the theme is the influential factors when teaching, and the subthemes are the challenges and facilities that they get during work with very young learners.

For the first theme, the teachers in Star Kids not aware of young learners. Most of them not know about the characteristics and teach only by instinct. According to the interview data, the teachers rarely read books about young learners. They only do the things told by the senior or headmaster. They are rarely going to a seminar to upgrade their knowledge. They only can use simple English expressions and asking the parents about their progress at home. Even though hard, the teacher always teaches with heart and ready to learn more about young learners.

For the second theme, the teachers use all media in teaching their class, especially teaching English. After school, they will gather and discuss what media will be appropriate to use for tomorrow. They have lesson plans and try to do all of the activities. Every day they use songs but always English songs. Sometimes they use Indonesian songs too. Pictures, videos, and puppets are the media that the teacher usually uses. For songs themselves, mostly use music videos from youtube. 
AN INVESTIGATION OF ENGLISH DEVELOPMENT OF YOUNG LEARNERS AT STAR KIDS PRESCHOOL

For the third theme, challenges faced by the teachers in dealing with young learners are various. The teachers agreed that working with young learners is not always easy. They need help in anything that starts with simple things such as going to the bathroom, eating. When the writer interviewed the teacher, they agree that sometimes they feel tired, but mostly, they become more patient when dealing with the learners. They get a better understanding of them during teaching even though they have very minimal knowledge about them. They get support and facilities from school during teaching. They get various media such as pictures, flashcards, songs, music videoss for children, and books. Nevertheless, they agree that they should get more knowledge about young learners by attending workshops, courses, or seminars. The school rarely sends them going to such activities.

According to the parents, the teachers already give their best. They always report learners' development at school as well as their understanding of English. Some of the parents realize that they also do not know about English, and it a problem for the parents because when the learners want to study at home, they cannot help them. However, they are glad and proud when their children can use simple English at home. The parents also realize that the teachers help the learners become confident. The teachers always maintain good communication with the parents, so they know the development of the learners at school. So, mostly the parents satisfy with how the teachers help the learners at school.

The interview with the headmaster was helpful to see whether the teachers in Star Kids answer the interview properly. According to the headmaster, the teachers helpful in teaching English to young learners. She agrees that not all the teachers are from English development even though the school mostly using English in class. She is also aware that sometimes the teachers made mistakes. Usually, after the teaching and learning process, they gather and discuss the mistake. However, until today, the mistake is only about forgetting to use one or two simple words or expressions using English. In the future, she hopes that all teachers can follow many seminars about teaching young learners. According to her, communication between parents, teachers, and school is well.

\section{Conclusion and Suggestion}

\section{A. Conclusion}


AN INVESTIGATION OF ENGLISH DEVELOPMENT OF YOUNG LEARNERS AT STAR KIDS PRESCHOOL

This research aimed to investigate the English development of young learners at Star Kids preschool. The writer used a case study approach in this research. The data were gathered from observation and semi-structured interviews with teachers, parents, and the headmaster of the preschool.

The findings from observation indicate that the teachers lack knowledge in teaching young learners and mostly are not from the English department. However, the teachers very patient in teaching the learners. Sometimes they make mistakes in the class but mostly about simple things such as forget to use English words to praise the learners. The teachers help the learners become more independent and confident in using simple English words or expressions.

Besides observation, the teachers participated in the semi-structured interviews. They agree that the school rarely give them seminar or courses about how to teach young learners properly. They got full support from the school regarding teaching materials. They generally showed supportive attitudes towards the young learners. The parents and the headmaster also participated in a semistructured interview. They agree that the teachers are really helpful and always try to maintain good communication with them.

\section{B. Suggestion}

This research identified several issues regarding teachers' knowledge of young learners. Teachers play a vital role in the success of the implementation of any educational idea or concept. The writer pointed out only one suggestion; the teachers in Star Kids need to improve their knowledge about young learners learners through books, seminar/workshop, or courses to give sufficient information about the proper way to teach them.

\section{References}

Brewster, J., Ellis, G.,\& Girard, D. The Primary English Teacher's Guide (New Edition). England: Pearson Education Limited. 2004

Cameron, L. Teaching Languages to Children. Cambridge: University Press. 2001

DeMarrais, K.B., \& Lapan, S.D. Foundations for Research: Methods of Inquiry in Education and The Social Sciences. Mahwah, N.J: Erlbaum Associates. 2007

Ersoz, A. Teaching English to Young Learners. Ankara: EDM Publishing, 2007 
AN INVESTIGATION OF ENGLISH DEVELOPMENT OF YOUNG LEARNERS AT STAR KIDS PRESCHOOL

Eurydice. Content and Language Integrated Learning (CLIL) at School in Europe.

Brussels: Eurydice European Unit. 2006

Gerring, John. What is a Case Study and What is It Good For? American Political Science Review Vol. 98, No.2 May, 2004

Gordon, T. Teaching Young Children A Second Language. USA: Praeger Publisher. 2007

Harmer, J. The Practice of English Language Teaching (4th Ed.). Essex: Pearson Longman. 2007

Larsen-Freeman, D. Techniques and Principles in Language Teaching. Oxford, UK: Oxford University Press. 2000

Mixon, M \& Temu, P. First Road to Learning Language Through Stories. English Teaching Forum, 44 (2), 14-19. 2006

Phillips, S. Young Learners (2nd Ed.). Oxford, UK: Oxford University Press. 1994

Richards, J.C \& Rodgers, T.S. Approaches and Methods in Language Teaching. Cambridge, UK: Cambridge University Press. 2001

Scott, W.A., \& Ytreberg, L.H. Teaching English to Children (14th Ed.). New York: Longman. 2001

Shin, J.K. Ten Helpful Ideas for Teaching English to Young Learners. English Teaching Forum, 44 (2), 2-13. 2006

University of Cambridge. Teaching Knowledge Test (TKT) Young Learners (YL) Handbook for Teachers. United Kingdom: Cambridge, 2010 